\title{
Improving The Quality of Tofu Waste as A Source of Feed Through Fermentation Using the Bacillus amyloliquefaciens Culture
}

\author{
Anggraeni $^{\#}$, Sawarni Hasibuan ${ }^{*}$ Burhanuddin Malik\#, Rizza Wijaya ${ }^{* *}$ \\ \# Animal Husbandry Department, Bogor Djuanda University, Bogor \\ E-mail: angraeni_tnk@yahoo.co.id \\ * Agroindustrial Technology Department, Bogor Agricultural University, Bogor \\ E-mail:sawarni02@yahoo.com \\ **Animal Husbandry Program Alumni, Bogor Djuanda University, Bogor \\ E-mail: burhanudinmalik@yahoo.com
}

\begin{abstract}
High levels of crude fiber contained in tofu waste become a limiting factor for its use as a source of feed. The purpose of this research is to improve the quality of tofu waste as a source of feed through the ensilage process using the Bacillus amyloliquefaciens bacteria. The design used was the Factorial Complete Random Design with two treatments, i.e. the Bacillus amyloliquefaciens concentration and fermentation time. This research used three Bacillus amyloliquefaciens concentrations, i.e. $5 \%$, $10 \%$, and $15 \%$, and six fermentation times, i.e. 2 days, 3 days, 4 days, 5 days, 6 days, and 7 days. Based on the analysis of variance, the treatment of Bacillus amyloliquefaciens concentration and fermentation time and their interaction had an effect on the level of crude fiber and the total silage acid of tofu waste $(P<0.01)$, but did not have an effect on its water level $(P>0.05)$. The greater the dose of Bacillus amyloliquefaciens inoculated on the tofu waste, the smaller the average value of its crude fiber; contrary to the total lactic acid produced. The best treatment was obtained at doses of Bacillus amyloliquefaciens of $15 \%$ fermented for 5 days with an average of crude fiber level of $17.3 \%$ and total acid average of $0.87 \%$, which means they meet the requirements of SNI (Indonesian National Standard) for the ideal total acid criteria, i.e. 0.5-2.0\%. A decline in the level of silage crude fiber of tofu waste reached $44 \%$ compared to tofu waste raw material. Based on the organoleptic test, the silage resulting from the fermentation of Bacillus amyloliquefaciens with a $15 \%$ dose had the best aroma, color and texture compared to doses of $5 \%$ and $10 \%$.
\end{abstract}

Keywords - Tofu waste; Feed; Silage; Bacillus Amyloliquefaciens.

\section{INTRODUCTION}

Tofu waste is solid waste from tofu factories. The nutritional content of tofu waste is quite high, containing crude protein of $22.64 \%$ and gross energy of $4010 \mathrm{kcal} / \mathrm{kg}$ [1]. Although tofu waste has a nutritional composition sufficient for use as poultry feed, it is assumed that the use of tofu waste in duck feed is limited. The limited use of tofu waste as poultry feed is due to its high content of mineral, fat and crude fiber.

In order that tofu waste can be used in larger portions in feed, there is the need for a touch of technology to improve the nutritional value of the feed. The high content of crude fiber in tofu waste can be overcome by fermentation. The fermentation process is capable to simplify the particles of feed ingredients, so as to improve its nutritional value. Feed ingredients that have undergone fermentation would be better in quality than raw material that has not undergone the fermentation process.

The fermentation process of feed ingredients can be carried out naturally, with an addition of organic acid, or with microbial inoculation. Besides helping to improve the efficiency of the fermentation process of feed ingredients, the use of microbes acts as a probiotic as well. Various species of microbes have been used as probiotics in animal feed. Species of microbes in probiotics are considered to have characterisics as microorganisms that can improve health conditions and are safe to be consumed.

The addition of probiotics in tofu waste aims to increase the digestibility of protein and crude fiber through fermentation. The Bacillus amyloliquefaciens microbe can be inoculated in the fermentation of tofu waste, considering its potential in the production of the amylase enzyme. Bacillus sp. is one of the microorganisms that is declared safe as a feed additive by the European Food Safety Authority (EFSA). The above mentioned microbe species is considered to have the 
characteristics as a microorganism that can improve health conditions and is safe for livestock. Bacillus amyloliquefaciens comes from soil that was discovered by a Japanese biologist named Fukumoto in 1942 [2]. It is also said that Bacillus amyloliquefaciens is part of the species Bacillus subtilis which produces the amylase enzyme that is capable of hydrolyzing starch and can synthesize subtiline which is an enzyme that catalyzes protein as does the enzyme trypsin $[3,2,4,5]$.

Seeing the potential of Bacillus amyloliquefaciens in improving the nutritional quality of some waste, it is apparently necessary to carry out a research to determine the possible use of the inoculum in improving the quality of tofu waste to be applied in poultry feed, particularly that of ducks. $[6,1,7,8]$.

The objective of the research is to determine the effects of Bacillus amyloliquefaciens microbe concentrations and fermentation time on the quality of tofu waste silage in order to be able to increase the efficiency of poultry production costs, particularly for local broiler ducks.

\section{RESEARCH METHOD}

Implementation of the research took place at the Chemistry Laboratory of Djuanda University in Bogor from

May 2012 to October 2012. Materials used in the research were fresh tofu waste, Bacillus amyloliquefaciens bacterial culture, as well as chemicals for analysis, such as distilled water, $\mathrm{H}_{2} \mathrm{SO}_{4}$, hexane, $\mathrm{H}_{3} \mathrm{BO}_{3}, 0.1 \mathrm{~N} \mathrm{HCl}, 3.25 \% \mathrm{NaOH}$, $\mathrm{H}_{2} \mathrm{SO}_{4}$, and $40 \% \mathrm{NaOH}$.

The equipment used in this research were digital scales, polyethylene packages, dishes and rubber bands, litmus paper, Erlenmeyer tubes, pipettes, beakers, analytical scales, oven, exicator, tongs, petri dishes, vacuum, biuret, and filter paper.

Stages in the fermentation process of tofu waste silage using Bacillus amyloliquefaciens cultures performed in this research are presented in Figure 1. In the initial stage, a proximate test on tofu waste raw material was performed, then the fermentation process was performed using Bacillus amyloliquefaciens inoculums with various concentrations for seven days. Silage quality was observed on the $2 \mathrm{nd}, 3 \mathrm{rd}, 4 \mathrm{th}$, 5 th, 6 th, and 7 th day.

The experimental design used was the Factorial Completely Randomized Design (Factorial CRD) using the linear model of the analysis of variance as follows:

$\mathrm{Y}_{\mathrm{ij}}=\mu+\mathrm{A}_{\mathrm{i}}+\mathrm{B}_{\mathrm{j}}+\mathrm{AB}_{\mathrm{ij}}+\varepsilon_{\mathrm{ijk}}$

where :

$\mathrm{Y}_{\mathrm{ijk}}=$ Response variable of observation

$\mu=$ General average of population

$A_{i}=$ The effect of treatment $A$ is the $\mathrm{i}$-th inoculum concentration $(5 \%, 10 \%, 15 \%)$

$B_{j}=$ The effect of treatment $B$ is the $\mathrm{j}$-th fermentation length $(2,3,4,5,6,7$ days $)$

$\mathrm{AB}_{\mathrm{ij}}=$ The effect of the combination of treatment $\mathrm{A}$ of the $\mathrm{i}-$ th stage and treatment $B$ at the $j$-th stage

$\varepsilon_{\mathrm{ijk}}=$ The residual effect_of the k-th replication unit and the $\mathrm{i}$-th and $\mathrm{j}$-th treatment

The analysis of variance was performed at the significance level of 5\% and $10 \%$. Duncan's test was used to compare the mean difference between significant treatments. The analysis of the quality of silage as a product of tofu waste fermentation was based on the parameters of water content [9], crude fiber content [9], degree of acidity $(\mathrm{pH})$, total acid as lactic acid [9], and the physical properties of silage (texture, color, aroma and the presence of fungi).

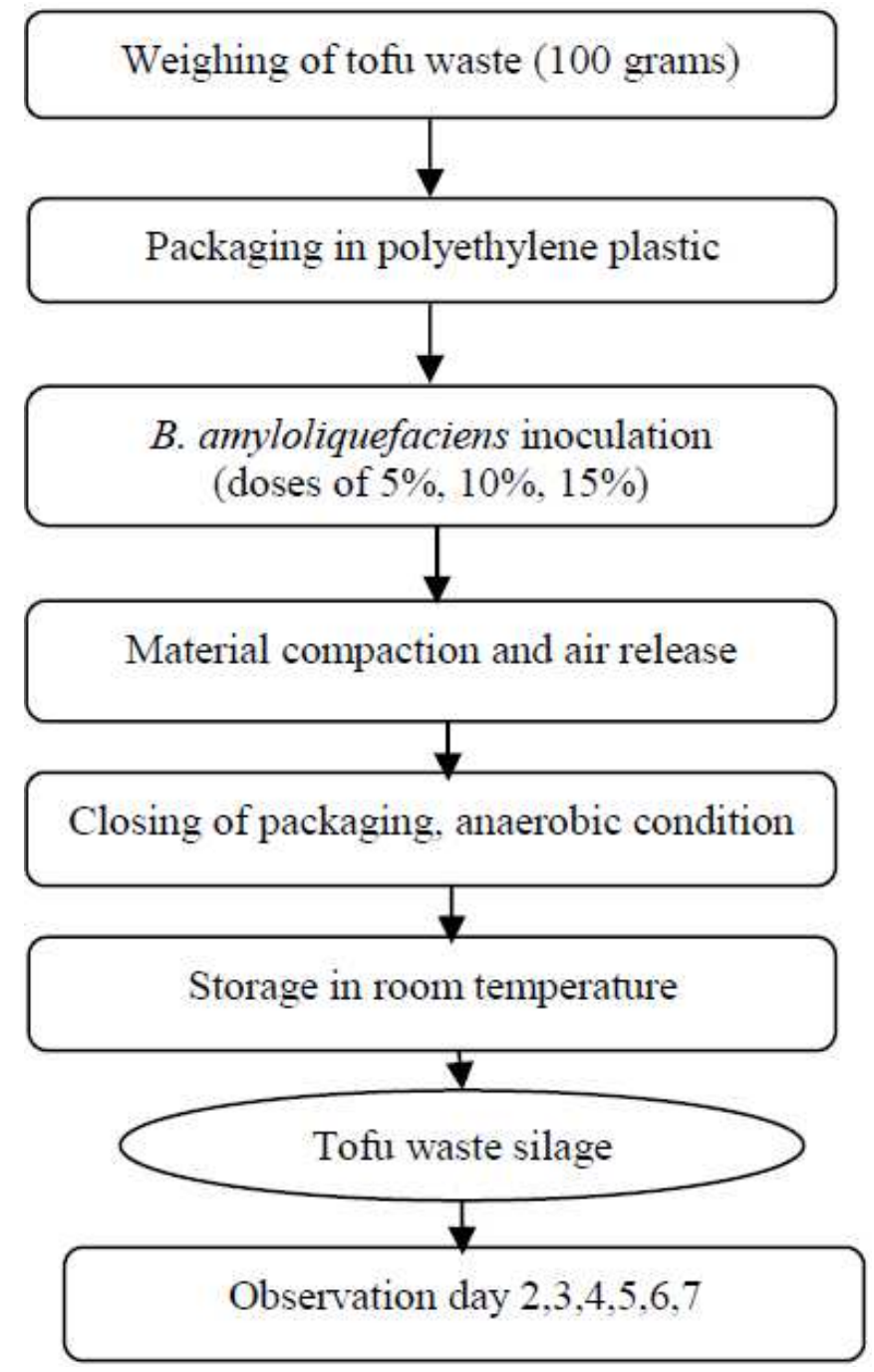

Fig. 1 Fermentation process of tofu waste using Bacillus amyloliquefaciens

\section{RESULT AND DISCUSSION}

The tofu waste used in the research came from a tofu factory in the Darmaga area in Bogor, with a composition as presented in Table 1. Tofu waste raw material has a high water content so that it is easily decayed and has a short shelf life. However, the crude protein content in tofu waste is quite high and is potentially used as poultry feed through fermentation. 
TABLE I

COMPOSITION OF THE NUTRITIONAL CONTENT OF TOFU WASTE

\begin{tabular}{|l|c|c|}
\hline Composition & As Feed & Dry Matter \\
\hline Water Content & $90.04 \%$ & $0.00 \%$ \\
Ash Content & $0.17 \%$ & $1.71 \%$ \\
Crude Protein & $3.48 \%$ & $34.94 \%$ \\
Crude Fat & $2.04 \%$ & $20.47 \%$ \\
Crude Fiber & $3.93 \%$ & $39.46 \%$ \\
Beta-N & $0.34 \%$ & $3.43 \%$ \\
\hline Total & $100 \%$ & $100 \%$ \\
\hline
\end{tabular}

\section{A. Water Content}

The average water content of fermented tofu waste using various doses of Bacillus amyloliquefaciens inoculum for 7 days of fermentation ranged between 92.42 to $93.58 \%$. Increased inoculum concentrations and length of fermentation tended to increase the average water content of tofu waste silage, but results of the analysis of variance showed that the treatment of applying doses of Bacillus amyloliquefaciens inoculum and length of fermentation as well as their interactions did not have a significant effect $(\mathrm{P}>0.05)$ on the water content of tofu waste.

\section{B. Crude Fiber}

The average crude fiber of tofu waste silage produced canbe seen in Table 2. Based on the results Weighing of tofu waste (100 grams) Packaging in polyethylene plastic B. amyloliquefaciens inoculation (doses of $5 \%, 10 \%, 15 \%$ ) Material compaction and air release Closing of packaging, anaerobic condition Storage in room temperature Tofu waste silage Observation day 2,3,4,5,6,7 of the analysis of variance, treatments of inoculum doses, length of fermentaion, and their interaction gave a highly significant effect $(\mathrm{P}<0.01)$.

The larger the dose of bacteria inoculated in tofu waste, the smaller the average value of its crude fiber. The average value of crude fiber content in tofu waste without treatment is higher than that in tofu waste that has been fermented. Wizna et al. reported that studies on fermentation in cassava pulp using Bacillus amyloliquefaciens inoculum showed that the content of silage crude fiber in cassava pulp with an inoculum dose of $10 \%$ was lower than that with inoculums doses of $2 \%$ and $6 \%$. [10] Title must be in 18 pt Regular font. Author name must be in $11 \mathrm{pt}$ Regular font. Author affiliation must be in 10 pt Italic. Email address must be in 9 pt Courier Regular font.

TABLE III

AVERAGE CRUDE FIBER OF TOFU WASTE SILAGE (\%)

\begin{tabular}{|c|c|c|c|c|}
\hline Length of Ferwentition & & noculium dose & & A \\
\hline (dxys) & Al & A2 & $A^{3}$ & Aleager \\
\hline Bl & $31.14 \pm 0.81^{x}$ & $32.71 \pm 3.377^{c}$ & $29.32 \pm 3.44^{x}$ & $31.05 \pm 2.67^{2 x}$ \\
\hline$B 6$ & $34.19 \pm 5.084^{1 x}$ & $36.42 \pm 7.40^{\circ}$ & $33.35 \pm 5.10^{x}$ & $34.86=4.82^{2}$ \\
\hline Average & $33.42 \pm 2.54^{\circ}$ & $31.20 \pm 5.73^{6}$ & $27.26=7.52^{1}$ & \\
\hline
\end{tabular}

Description: The same letter in a column or row is not significant at the significance level $(\mathrm{P}>0.05)$.

\section{Total Acid}

Treatments of inoculum doses, length of fermentation, and their interaction gave a highly significant effect on the total lactic acid of tofu waste silage $(\mathrm{P}<0.01)$. Results of Duncan's test showed that the addition of doses of Bacillus amyloliquefaciens inoculum in tofu waste silage increased the total content of lactic acid. The application of Bacillus amyloliquefaciens bacterium with a concentration of $15 \%$ had the highest average value of total lactic acid, i.e. 0.6151 $\mathrm{mg} / 100 \mathrm{~g}$.

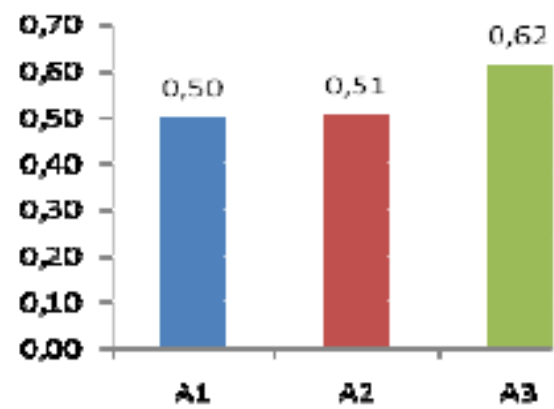

Fig. 1 Bar graph on the effect of Bacillus inoculum doses on the average total acid (\%) of tofu waste silage for 7 days of fermentation.

In Figure 2, it is seen that the total content of lactic acid in tofu waste silage was affected by the length offermentation. The average value of total lactic acid increased with the number of days of fermentation. The effect of interaction between treatments of inoculum doses and length of fermentation on the total lactic acid of tofu waste silage was highly significantly different $(\mathrm{P}<0.01)$. The highest average value of total acid was obtained on the treatment of an inoculum dose of $15 \%$ and fermentation length of 7 days. In the research of Uun Kunaepah, it is mentioned that according to the Indonesian National Standard (SNI), the ideal total acid ranges between 0.5 to $2.0 \%$. [7] The total silage acid of tofu waste produced was still in the range of the ideal total acid according to SNI in all the treatments.

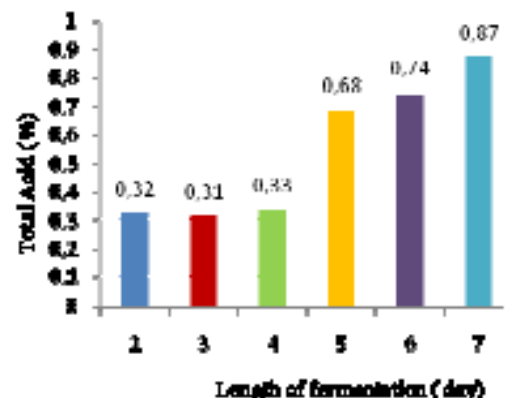

Fig. 2 Bar graph on the effect of fermentation length on the total acid (\%) of tofu waste silage with a treatment of Bacillus amyloliquefaciens bacterium.

\section{Degree of Acidity ( $p H)$}

The degree of acidity $(\mathrm{pH})$ is a key condition for the preservation of silage. The appropriate degree of acidity or $\mathrm{pH}$ is highly necessary to prevent any unwanted organisms in the silage making process. [11] The degree of acidity $(\mathrm{pH})$ of each treatment did not change after fermentation was performed, i.e. since 2 to 7 days of fermentation, which was 4 . The quality of this tofu waste silage comes under indication of good quality because it had a $\mathrm{pH}$ value less than 4.5. According to Kung and Nylon, in silage containing high water levels, a lower $\mathrm{pH}$ indicates better quality. [12]

\section{E. Color}


Tofu waste that was fermented using Bacillus amyloliquefaciens up to 7 days had a white or bright white color that tended to be stable. However, in the control, a change into a more turbid color occurred on day 5. On day 7 , it even changed into a yellowish color because the tofu waste had decayed. Viewed from its color, it can be concluded that a preservation of the tofu waste had occurred. According to Collins et al., the color in the silage is affected by bacterial activity during the fermentation process, and will affect the $\mathrm{pH}$ resulted. [13]

\section{F. Aroma.}

The smell of silage varies depending on the type of bacteria that plays an active role during the fermentation process and the presence of fungi that grows on the silage. The increase of inoculum dose resulted in an increase of acid aroma in the tofu waste silage. Theuse of bacterial doses of $10 \%$ and $15 \%$ were able to maintain the quality of silage based on the aroma of tofu waste silage up to 7 days of fermentation.

\section{G. Texture.}

The texture of tofu waste silage can affect the palatability of livestock in consuming it. Therefore, tofu waste silage is expected to have a good texture so that it lasts longer. The texture of silage has different characteristics depending on its ingredients and the results of anaerobic fermentation in a certain period. A fine and soft texture is a good texture to be given to livestock. According to Collins et al (1992), a fine and soft texture of silage tends to have high metabolic energy (ME) and the possibility of high crude protein. Tofu waste silage from each treatment had a soft texture, except the control that had undergone 7 days of fermentation had a rough texture and was a bit dry. The whole tofu waste silage produced had not become slimy until the 7 th day of fermentation.

\section{CONCLUSIONS}

The treatment of inoculum doses of Bacillus liquefaciens bacterium, the length of fermentation, and their interaction gives a significant effect on the crude fiber $(\mathrm{P}<0.05)$ and total lactic acid of tofu waste silage $(\mathrm{P}<0.01)$. The higher the dose of bacteria inoculated in the tofu waste, the smaller the value of its average crude fiber; contrary to the total lactic acid produced. The best treatment was obtained at doses of Bacillus liquefaciens of $15 \%$ that was fermented for 5 days with a crude fiber content of $17.3 \%$ and a total acid of $0.87 \%$, which means it meets the requirements of SNI for the ideal total acid in feed, i.e. $0.5-2.0 \%$. The decrease of crude fiber content in the tofu waste silage reached $40.95 \%$ compared to the condition of tofu waste silage on the 2 nd day of fermentation. Organoleptically, the silage resulting from the fermentation of Bacillus liquefaciens with a dose of $15 \%$ had the best aroma, color and texture compared to doses of $5 \%$ and $10 \%$.

\section{REFERENCES}

[1] Tanwiriah Wiwin, Dani Garnida dan Indrawati Yudha Asmara. 2006 Pengaruh Tingkat Pemberian Ampas Tahu Dalam Ransum Terhadap Performan Entog (Muscovy Duck) Pada Periode Pertumbuhan.

[2] Priest, F.G., M. Goodfellow, L.A. Shute and R.C.W. Berkeley. 1987. Bacillus amyloliquefaciens sp.nov.,nom. Rev. Int. J. Syst. Bacteriol. $37,69-71$
[3] Fuller, R. 1989. Probiotik in man and animals. Journal of Applied Bacteriology. 66:365-378.

[4] Rolfe, R.D. 2000. The role of probiotic culture in the control of gastrointestinal health. Journal of Nutrition. 130:396S-402S

[5] Simon, O. 2005. Micro-organisms as feed additives - probiotics. Advances in Pork Production (2005). 16;161.

[6] Uhi, T. Hari, Wiro, T, Batseba, Siska Tirajoh dan Usman H.S. 1999. Pengkajian Teknologi Pemanfaatam Ampas Tahu Sebagai Pakan Ayam Buras Di Kabupaten Nabire. Prosiding Seminar Nasional Peternakan dan Veteriner. Pusat Penelitian Peternakan Departemen Pertanian. Bogor.

[7] Santoso U. 2009. Pemanfaatan Ampas Tahu Pada Pakan Unggas. http://far71.wordpress.com/2011/04/06/pemanfaatan-ampastahupadaunggas /. [ 25 September 2012]

[8] Gustina. 2012. Pemanfaatan Ampas Tahu Sebagai Pakan Unggas.Jurusan Peternakan. Faperta. Universitas Bengkulu. Bengkulu.

[9] [AOAC]. Association of Official Agricultural Chemists. 1999. Official Methods of Analysis of AOAC International. Maryland,USA.

[10] Wizna, Hafil Abbas, Yose Rizal, Abdi Dharma and I. Putu Kompiang, 2009. Improving the quality of Tapioca by-products (Onggok) as poultry feed through fermentation by Bacillus amyloliquefaciens. Pak. J. Nutr., 8: 1636-1640.

[11] Frost, G.M. and D.A. Most. 1987. Production of enzymes by fermentation. In Biotechnology, Vol. 7a, J.F. Kenedy. (ed) Verlag Chemie, Weinheim, pp. 65-211.

[12] Kung, D dan Nylon., S. 2001. Tropical Tuber Croops. Jhon Whileys and Sons. Chicester. UK.

[13] Collins, M. Martens, D.R and Moser, L. 1992. Forage Quality, Evaluations, and Using. ASA, CSSA, and SSSA. Madison, Wisconsin. pp 229-280. S. M. Metev and V. P. Veiko, Laser Assisted Microtechnology, 2nd ed., R. M. Osgood, Jr., Ed. Berlin, Germany: Springer-Verlag, 1998. 